\title{
Understanding Civic Crowdfunding as a Mechanism for Leveraging Civic Engagement and Urban Innovation
}

\author{
Bastiaan Baccarne, Tom Evens, Lieven De Marez
}

\author{
"Crowdfunding is not about the funding, it's about the crowd." \\ Anonymized study respondent
}

\begin{abstract}
This article studies the emergence of government-initiated civic crowdfunding platforms. Such platforms can be considered as governmental responses for bottom-up peer-to-peer support mechanisms related to urban innovation, which also allows top-down governance and governmental support systems for civic entrepreneurship. To better understand the implications of these innovative ICT-enabled interaction interfaces for collective urban innovation, this study investigates participation inequalities from the perspective of campaign instigators, using in-depth interviews $(\mathrm{N}=28)$, and from the perspective of the citizen-funder, using a survey $(\mathrm{N}=265)$. The analysis shows that urban crowdfunding practices mainly contribute to higher-level development of collective identities with increased neighborhood capacities. Although participation in such ICTenabled interaction interfaces could reinforce digital inequalities and existing power balances, this research shows a more nuanced perspective, in which online and offline practices intertwine. Furthermore, while civic crowdfunding campaigns are driven by a traditional 'participation elite', the deliberation process on development projects involves new publics that are not typically engaged in civic activities. Hence, civic crowdfunding formulates a new mode of civic engagement in which institutional involvement acts as a trust broker between civic funders and civic entrepreneurs, as well as adding legitimacy to innovation processes in the public sphere.
\end{abstract}

\section{Introduction}

Over the past decade, crowdfunding has emerged as a peer-to-peer (P2P) digital technology. It enables a new way to receive support for entrepreneurship in various domains, including canvassing grassroots urban initiatives and tactical urbanism, often with a societal orientation (Stiver et al., 2015). However, such 'civic' (meaning, 'from the citizens') crowdfunding initiatives at the same time contribute to a growing tension between increasingly empowered bottom-up peer-topeer innovation processes and the top-down management of urban innovation (Davies, 2015). Hence, in line with broader challenges regarding the peer-topeer economy, local governments are faced with questions regarding adequate governance models against over-the-top models for urban innovation, especially in a public-democratic context (Koopman et al., 2015).
Governments generally are increasingly exploring new modes of governance that tend to shift from 'rules' to 'tools' (Holverson, 2017). This also encompasses the implementation of 'government-owned' civic crowdfunding platforms, on which policy and grassroots initiatives can interact. They allow governments to integrate civic entrepreneurship in existing support and control processes such as funding programs (Stiver et al., 2015; Lee et al., 2016). On top of that, these initiatives can also be interpreted as a way of shifting investments from centralized governments to distributed 'crowds', in a way that lines up with the broader neo-liberal tendency to optimize efficiency, which is often related to budget cuts (Brenner \& Theodore, 2002; Lee et al., 2016).

On the other hand, 'government-owned' civic crowdfunding initiatives can also be situated within the broader transformation from government managerial control, towards participation and ownership of societal 


\section{Understanding Civic Crowdfunding as a Mechanism for Leveraging Civic Engagement and Urban Innovation Bastiaan Baccarne, Tom Evens, Lieven De Marez}

actors and civic entrepreneurship (Janssen \& Estevez, 2013). From a positive, techno-optimistic perspective it is believed that this leads to civic empowerment (Carè et al., 2018), through which civic or socially-oriented entrepreneurs can take (joint) action that is inherently positive for society. However, this entrepreneurial focus also has implications for the democratic aspect of urban innovation, adding to the conceptualization of digital citizenship (Mossberger et al., 2008). Often, (both theoretical and practical) knowledge, processes and even technologies are adopted from a commercial context. It is clear, however, that civic applications of the adopted platforms come with questions and challenges specific to their implementation in a public-democratic context (Lee et al., 2016; Logue \& Grimes, 2019).

An increased participatory potential also implies an increased individual citizen responsibility to adopt these instruments, which can be conceptualized as (a subset of) online civic engagement (Kligler-vilenchik, 2017). Research has shown that digital participation interfaces have the potential to involve wider audiences, engage younger citizens, and support communities (Fredericks \& Foth, 2013), but that those who participate tend to be highly educated and already well connected with local institutions (Tonkens et al., 2015). This reveals some of the (potential) inequality patterns that can be observed in the adoption of online civic engagement practices. More specifically, urban technologies such as civic crowdfunding platforms are appropriated as co-production places (Forlano, 2013), and thus also raise several issues regarding legitimacy and responsibility. For example, new ownership models have started emerging when cities are shaped through such digital participation interfaces (de Lange \& de Waal, 2013; Lee et al., 2016).

This study therefore explores individual participation inequalities in civic crowdfunding. It aims to contribute to the current theoretical understanding in regard to the legitimacy and democratic aspects of such initiatives. It also illustrates and supports policy decisions regarding the implementation of government-owned civic crowdfunding platforms.

\section{Research Framework}

\section{Civic crowdfunding}

Since 2008, crowdfunding has emerged as a technologyenabled platform-based mechanism to obtain project resources. It builds upon (usually) small donations by a large group of 'backers' (Davies, 2015), usually without the involvement of traditional investors, such as financial institutions. Hence it enables new and interesting dynamics for entrepreneurship (Mollick, 2014). Civic crowdfunding is considered a subset of crowdfunding that entails those projects aimed at tackling societal challenges or community needs, as a form of social enterprise (Mayer, 2018). As such, it is an instrument to empower civic or social entrepreneurs whose aim is to contribute to society by stimulating the cultural and social domains.

In this context, projects are being financed by inhabitants of a neighborhood, city or region. This also implies that civic crowdfunding practices are closely entangled with broader practices of citizenship and civic (national) engagement, establishing new interaction possibilities with policy and policymaking (Brabham, 2009). Or, as O'Connor (2012) put it: civic crowdfunding can "open up the possibility for the commons to participate within the political and economic system of the state and compete against large corporations which in turn influences the 'democratic' practices of the state". Therefore, it is not unexpected that (local) governments proactively shape and govern such crowdfunding platforms to be able to in some way manage or at least contribute to bottom-up practices. They can then be embedded as part of the (local) policy toolbox (Carè et al., 2018).

\section{Inequalities in civic crowdfunding}

Hence, as the diffusion of such participatory communication technologies proceeds, they start to play an increasingly important role in the way citizens engage themselves politically and socially. Authors such as Castells (2007) stress that access and usage of such technologies have become an important aspect in the acquisition of wealth, power, and knowledge. However, as was introduced earlier, access, skills, and especially usage of such technologies are not distributed equally (Mossberger et al., 2008). In the digital age, there are still differences in technology access and usage, and in the uptake of the empowering potential of new online participatory platforms (Van Dijk \& Hacker, 2003 Dimaggio et al, 2004; Jenkins et al., 2006; Hargittai \& Hinnant, 2008). So, while digital platforms increasingly empower citizens, participation on these platforms is not distributed evenly across society, which might confirm or reinforce existing power imbalances (Albrecht, 2006; Davies, 2015).

On the one hand, such inequalities are often studied from a socio-demographic perspective. For example, research has shown that online civic participation platforms engage mainly younger citizens (Fredericks \& 


\section{Understanding Civic Crowdfunding as a Mechanism for Leveraging Civic Engagement and Urban Innovation Bastiaan Baccarne, Tom Evens, Lieven De Marez}

Foth, 2013) who are highly educated (Stern \& Dillman, 2006), and well connected with local institutions (Tonkens et al., 2015). Hence, a socio-demographic perspective to understand participation inequalities in civic crowdfunding will be the first perspective of this study. which will include the role of gender, age, income, education, occupation, and residency (cfr. Stiver et al., 2015). Complementary to this socio-demographic approach, we take a 'uses and gratifications' perspective that allows us to obtain a better understanding of motivations and expected outcomes (gratifications). This is implemented as an open-ended way of capturing latent drivers and barriers (in line with Charbit \& Desmoulins, 2017). Especially the relationship between instigators and backers, which distinguishes civic crowdfunding from traditional entrepreneurship (Hui et al., 2014), is taken into account.

A second perspective of this study is embedded in literature on digital citizenship (Mossberger et al., 2008), that builds upon insights regarding broader digital inequalities from a digital divide perspective. This is now possible since civic crowdfunding practices can be conceptualized as a subset of digital engagement (in line with Norris, 2001). Hence, this perspective allows the study of participation inequalities in civic crowdfunding within a broader context of digital literacy and digital engagement. Within this elaborate research domain, Van Deursen, Helsper and Eynon (2014) built upon an earlier digital literacy framework (Helsper \& Eynon, 2013) to distinguish five types of digital skills and four types of digital engagement. From these dimensions, in particular operational skills (to be able to handle ICT on a technical level) and digital engagement (the active usage of web technologies), are seen as relevant predictors of participation inequalities in civic crowdfunding.

\section{Civic engagement \& institutionalized participation}

As was mentioned earlier, the application of crowdfunding mechanisms in a societal context implies that such practices can be interpreted as a new mode of citizenship (Stiver et al., 2015). This relates to the notion of 'active citizenship' and 'civic engagement' (Mayer, 2018). These are concepts with a long history and often discussed definitions (Adler \& Goggin, 2005). They entail 'trying to make a difference' (Ehrlich, 2000; Adler \& Goggin, 2005) and 'solving problems' (Byrne, 2007), both in a political (Ehrlich, 2000; Byrne, 2007) and a community context (Ehrlich, 2000; Adler \& Goggin, 2005; Byrne, 2007). While these aspects assume explicit active aspects of citizenship, other authors distinguish between such active modes of civic participation, and a more latent dimension of (often online) communicational practices and civic involvement (Preece \& Shneiderman, 2009; Ostertag \& Ortiz, 2015). According to Bobek, Zaff, $\mathrm{Li}$ and Lerner (2009), active engaged citizenship should be interpreted as combining civic participation, civic engagement and social cohesion. This definition includes an even more latent dimension of 'civic identity' (Atkins \& Hart, 2003; Carè et al., 2018). Hence, this study explores the relationship between participation inequalities in civic crowdfunding and (1) civic engagement (offline practices), (2) online civic engagement (online communicational practices) and (3) civic identity (urban collective identifiers).

As mentioned earlier, governments are increasingly taking control over new modes of civic engagement. Their aim is to institutionalize these practices into more formal interactions that can be implemented in existing governance structures. Given the top-down ownership of government-initiated civic crowdfunding technologies, attitudes towards the government might contribute to our understanding of participation differences, especially when compared with non-formal notions of civic engagement (Lee et al., 2016). Authors such as Ekman and Amnå (2012), and Talò and Mannarini (2015), have made an explicit distinction between the community aspect of civic engagement and its political aspect. From this perspective, innovative ICT-mediated participation platforms are considered as an effort of governmental institutions to promote meaningful citizen engagement, thereby attempting to narrow the 'public-police disengagement gap' (Warren et al., 2014).

Our approach to this was twofold: First, we investigated the role of political efficacy in explaining participation inequalities, which entails the degree of agency an individual experiences towards local policy making (Craig et al., 2017). Second, we studied the government's role in these multi-actor collaborations in a more open way, in order to better understand the intertwined interactor dynamics of the institutionalized aspect of government-owned civic crowdfunding processes.

\section{Methodology}

To do this, this study utilizes a single case study design combining qualitative and quantitative research methods. The single case study entails the study of a single civic crowdfunding platform, initiated and controlled by a single local government. Hence, external 


\section{Understanding Civic Crowdfunding as a Mechanism for Leveraging Civic Engagement and Urban Innovation Bastiaan Baccarne, Tom Evens, Lieven De Marez}

contextual parameters were kept constant to ensure maximum internal validity and avoid confounding parameters outside the scope of this research (Yin, 1984). Building upon this central case, qualitative research was applied to study the perspective of citizenusers who instigated crowdfunding campaigns on the platform. Using in-depth interviews $(\mathrm{N}=28)$, we obtained a better understanding of the dynamics driving both their own behavior and the behavior of their funders. Next, these interviews were coded and implemented in an online survey studying the perspective of the citizenfunder $(\mathrm{N}=265)$.

\section{Research context}

The central case study is a civic crowdfunding platform built and governed by the local municipality of the city of Ghent, Belgium. This city has officially 220,640 inhabitants older than 15 (http://gent.buurtmonitor.be), in addition to around 30,000 students who live in the city on a temporary basis (http://kot.gent.be/cijfers-entrends). In 2015, the local government launched a crowdfunding platform to support bottom-up urban innovation (see info box).

\section{Data collection}

Given the boundaries of our central case study, the research population for this study is limited to inhabitants (both permanent and temporary) of the city of Ghent. For the in-depth interviews, our research population entailed project instigators, from which $26 \%$ was interviewed $(\mathrm{N}=28)$. As a sampling technique for the citizen-funder, we combined a convenience sample which was complemented with a quota sample, based on age and gender categories.

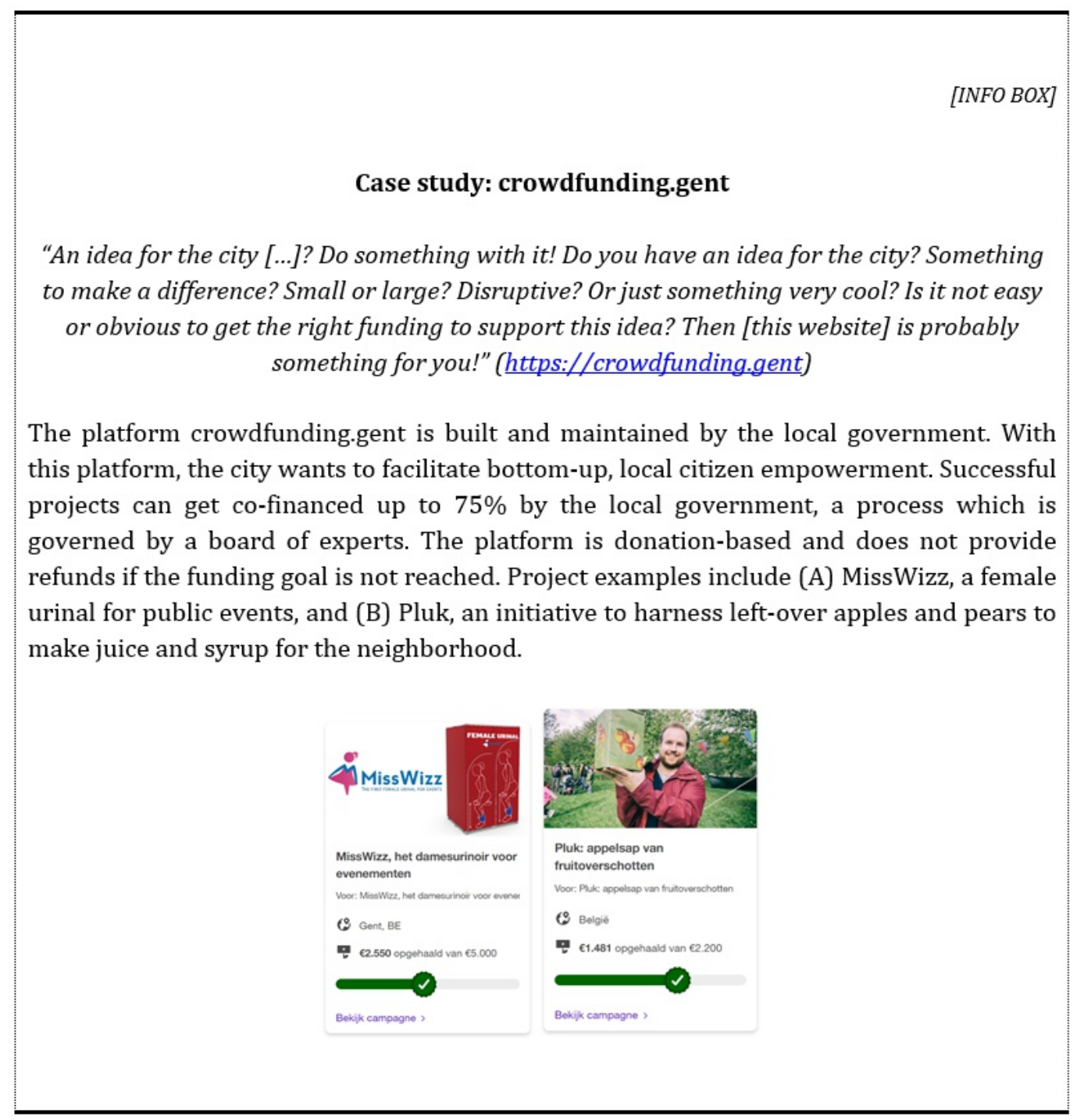

Figure 1. MissWizz (A) and Pluk (B). 


\section{Understanding Civic Crowdfunding as a Mechanism for Leveraging Civic Engagement and Urban Innovation Bastiaan Baccarne, Tom Evens, Lieven De Marez}

To avoid biases and participation inequality in the data collection itself, no digital skill-related measures were used for the quota sample. However, the recruiting activities were aimed at maximum inclusion of groups particularly with lower digital literacy. This recruiting took place online (newsletters, social media, targeted mailing), but mainly offline, through paper printouts (face-to-face in a public environment, more specifically in city-center streets, public places such as the local library and community locations, including public computer rooms at the local library).

The final sample, after data cleaning, entailed 265 respondents ( $42.6 \%$ male, 57.4 female). A more elaborate description of both the qualitative and quantitative research samples can be found in the addendum.

\section{Measures}

The in-depth interview used a semi-structured format, covering the following topics: (1) motivations, (2) digital citizenship, (3) civic engagement, and (4) the role of the government. The data were analyzed in an inductive manner using NViVo. Key elements in this analysis were implemented in the quantitative study. The survey applied the following measurements. All questions were framed using a seven-point Likert scale ( $1=$ totally disagree; $7=$ totally agree), unless otherwise mentioned.

Given the low number of citizen funders at the time the survey was conducted, and given the strong relationship between behavioral intention and actual behavior (Fishbein \& Ajzen, 1975), this survey first introduced the platform and projects, and afterwards investigated funding intentions. Funding intention was measured using items to analyze the citizens' intention to fund, in line with Davis (1989) (such as "I expect to fund such a civic crowdfunding project in the future"). This could be answered after exposure to a platform stimulus $(\alpha=.87$, $\mathrm{M}=4.13$, S.D.=1.42).

Seven central gratifications sought (such as "If I would fund such a project, it would be to improve my neighborhood") were derived from the interviews and implemented as Likert-items in the survey. In the analysis, we applied principle components analysis (PCA) to explore higher level dimensions. As discussed, we disentangled digital skills in two subdimensions (derived from van Deursen et al., 2014): operational skills $(\alpha=.80, \quad M=5.27, \quad$ S.D. $=1.31)$ and digital engagement $(\alpha=.89, \mathrm{M}=5.92$, S.D.=1.19). Civic entrepreneurship was disentangled in three subdimensions (adapted from
Jugert et al., 2013): traditional civic engagement ( $\alpha=.68$, $\mathrm{M}=2.08$, S.D. $=1.03)$, online civic engagement $(\alpha=.91$, $\mathrm{M}=2.36$, S.D. $=1.54)$, and civic identity $(\alpha=.81, \mathrm{M}=5,08$, S.D.=1.33). For the institutionalized aspect of civic crowdfunding, finally, we combined political efficacy (in line with Craig et al., 2017) and an explorative PCA-based analysis of seven interview-derived statements related to the role of the local government. More elaborate information on the measures used can be found in the addendum.

\section{Results}

\section{Socio-demographic aspects of funding intentions}

Considering traditional factors that might explain both participation inequalities as well as measures of the digital divide, this study investigates the role of six central socio-demographic variables in explaining funding intentions: gender, age, income, education, occupation, and residency. The results show that these dimensions only have a limited explanatory power regarding differences in funding intentions. While several studies mention that participants tend to be higher educated, our data shows no significant relationship between level of education and funding intention $(F(5)=2.04, p=0.07)$. Nor did we find any significant differences in funding intentions between occupations $(\mathrm{F}(9)=1.61, \mathrm{p}=0.11)$. Furthermore, contrary to what might be expected, income does not correlate significantly with funding intentions $(\mathrm{r}=-0.08, \mathrm{p}=0.21)$.

Due to the high number of temporary (often students) city inhabitants, we also controlled for funding intention differences between permanent $(\mathrm{M}=4.08$, S.D. $=1.54)$ and non-permanent $(\mathrm{M}=4.22$, S.D. $=1.20)$ residents, but this difference is not significant $(\mathrm{t}(252.14)=0.85, \mathrm{p}=0.34)$. Furthermore, male $(\mathrm{M}=4.04$, S.D. $=1.55)$ and female $(\mathrm{M}=4.20$, S.D. $=1.32)$ citizens do not have different funding intentions $(\mathrm{t}(217.67)=-0.93, \mathrm{p}=0.35)$. However, our data do confirm the hypothesis that such platforms attract younger citizens, since age is negatively correlated to funding intentions $(\mathrm{r}=-0.21, \mathrm{p}<.001)$. Hence, younger citizens have higher intentions to fund projects on government initiated civic crowdfunding platforms. However, age only explains $4.3 \%$ of the variation in funding intention $\left(\mathrm{R}^{2}=.043, \mathrm{~F}=11.80, \mathrm{df}=1\right.$, $\mathrm{p}<.001)$.

\section{Funding motivations}

The first topic of the in-depth interviews considered what drives funders to support a project. While 


\section{Understanding Civic Crowdfunding as a Mechanism for Leveraging Civic Engagement and Urban Innovation Bastiaan Baccarne, Tom Evens, Lieven De Marez}

crowdfunding is usually related to business investment, and contains a financial logic of extrinsic reward mechanisms, our qualitative research shows that altruistic motivations play an even more important role. Considering the social proximity of funders as a driver for funding motivation (friends and family), campaign instigators disagreed whether crowdfunding is able to access new social capital, or if it should rather be understood as a mechanism to access resources within existing networks of strong and weak ties. Although most respondents consider crowdfunding hard work, they also believe that as an online tool it has served to facilitate the generation of new network ties. Nevertheless, the importance of the project instigator's existing social capital is perceived as crucial for the ultimate success of the project.

"I think my existing network is the only reason my project achieved its goal" (male respondent, 42 years of age)

On the other hand, once projects take off, they tend to generate momentum, attracting wider audiences, in which the online environment allows for an amplification of this effect.

"Once you have a nice percentage, other people start getting convinced" (female respondent, 40)

"Uhm, what made it work? The social media that we've got" (female respondent, 24)

What is more, most project instigators even considered the social capital that was generated as more valuable than the (financial) resources they needed for the project. These new ties helped them strengthen the project and improved social cohesion in the neighborhood, leveraging neighborhood capacities beyond the scope of the project itself.

"I mean that's just like, [uhm] the money is only like the bread and butter, like it's the base" (male respondent, 26)

"Crowdfunding is not about the funding, it's about the crowd. It's actually more about the crowd than about the money." (female respondent, 49)

From the analysis of funding motivations, seven central dimensions could be derived, which were questioned using Likert statements in the survey (Table 1). The motivations of respondents were first analyzed using principle component analysis to reveal potential latent constructs, then checked for scale reliability using Cronbach's alpha, and finally tested in correlation with funding intentions (Table 1).

The PCA analysis for this study reveals three factors, which can be conceptualized as community altruism, individual rewards, and strong ties. Since the two items related to the factor 'individual rewards' did not show good scale validity metrics, we studied these as separate dimensions. Furthermore, this analysis shows that community altruism correlates very strongly with funding intention $(\mathrm{r}=0.41, \mathrm{p}<0.001)$. These data do not support strong social ties (accessing existing social capital), nor rational extrinsic trade logic as important factors to explain differences in funding intention, although non-material rewards are related with slight significance. This supports the assumption that strong ties only account for a limited aspect of crowdfunding dynamics. Community altruism explains $16.1 \%$ of the variation in funding intention $\left(\mathrm{R}^{2}=.164, \mathrm{~F}=51.75, \mathrm{df}=1\right.$, $\mathrm{p}<.001)$.

\section{Digital citizenship}

Regarding digital citizenship, this study investigated the relationship between crowdfunding intention and two metrics of digital literacy. Both digital operational skills (to be able to handle ICT on a technical level) and digital engagement (the active usage of web technologies) showed good scale reliabilities. It is worth noting that the means of both constructs were rather high (respectively 5.27 and 5.29), which suggests that, despite our efforts to include groups with lower digital literacy, our sample shows high average levels of digital literacy. However, both digital operational skills $(r=0.23, p<.001)$ and digital engagement $(\mathrm{r}=0.25, \mathrm{p}<.001)$ show significant and meaningful correlations with funding intention. When included in a multiple regression model, these constructs only explain $7.1 \%$ of the variation in civic crowdfunding intention $\left(\mathrm{R}^{2}=.071, \mathrm{~F}=10.02, \mathrm{df}=2, \mathrm{p}<.001\right)$. This might suggest a potential divide between those who are highly engaged in digital media and those who are technologically left behind. However, this analysis also reveals that individual contributions of the predictors are not significant, neither for operational skills $(\beta=0.13$, $t=1.63, p=0.11)$, nor for digital engagement $(\beta=0.21$, $\mathrm{t}=2.31, \mathrm{p}=0.02$ ).

This implies that traditional perspectives regarding the digital divide and its implications for digital citizenship only have limited value for understanding differences in funding intentions. Presumably, this could be explained 


\section{Understanding Civic Crowdfunding as a Mechanism for Leveraging Civic Engagement and Urban Innovation Bastiaan Baccarne, Tom Evens, Lieven De Marez}

Table 1. Motivations for civic crowdfunding in relation to funding intentions

\begin{tabular}{|c|c|c|c|c|c|c|}
\hline & $\begin{array}{l}\text { Factor } \\
\text { loading }\end{array}$ & $\begin{array}{c}\text { Cronbach's } \\
\alpha\end{array}$ & Mean & S.D. & $\mathbf{r}$ & $\mathbf{p}$ \\
\hline Community altruïsm & & 0.68 & 5.23 & 0.96 & 0.41 & $\begin{array}{c}< \\
0.001\end{array}$ \\
\hline $\begin{array}{l}\text { To help people with a good } \\
\text { idea }\end{array}$ & 0.75 & & & & & \\
\hline $\begin{array}{l}\text { To contribute to a societal } \\
\text { challenge }\end{array}$ & 0.72 & & & & & \\
\hline To improve my neighborhood & 0.69 & & & & & \\
\hline $\begin{array}{l}\text { To be part of a community in } \\
\text { my neighborhood }\end{array}$ & 0.56 & & & & & \\
\hline Individual rewards & & 0.45 & - & - & - & - \\
\hline To receive a material reward & 0.82 & & 3.40 & 1.80 & 0.10 & 0.10 \\
\hline $\begin{array}{l}\text { To receive a non-material } \\
\text { reward }\end{array}$ & 0.77 & & 4.42 & 1.80 & 0.18 & 0.01 \\
\hline \multicolumn{7}{|l|}{ Strong ties } \\
\hline To support people I know well & 0.88 & & 4.43 & 1.76 & -0.08 & 0.19 \\
\hline
\end{tabular}

due to the fact that civic crowdfunding practices blur online versus offline boundaries, as project instigators provide their own platforms in addition to the online infrastructure to facilitate donations in-situ. Although hyperlocal digital communication infrastructure (re)connects neighborhood residents, this cannot be studied separately from the tangible urban environment of cities or regions, as these interactions also extend beyond the digital interface.

"After all, I think about one third of my donations came from an envelope I left behind at the butcher in [street], which is a good friend of mine." (male respondent, 26)

Hence, participation through new modes of digital civic engagement should not be studied from a binary online versus offline perspective, as these practices occur across boundaries in a very flexible way. In this sense, the study should feed into a more complex understanding of e-inclusion and digital divides.

\section{Civic engagement}

This analysis explicitly distinguishes campaign instigators from citizen-funders. The qualitative research revealed very high levels of civic engagement for project instigators, who consider themselves as engaged more than average in society, and showed high levels of individual agency regarding their neighborhood. Hence, these campaign instigators can be considered hyperlocal opinion leaders with a wide variety of action-oriented engagements in the neighborhood. They consider themselves as a medium between politics, mass media and the general public. These prototypical civic or social entrepreneurs are, in all their civil society activities, looking for support mechanisms to leverage their ideas and initiatives. These actors are therefore often known to the local authorities as they make extensive use of both unsolicited and solicited participation practices.

At the level of the citizen-funder, civic engagement was measured at three levels of abstraction. Firstly, civic engagement measures the intensity of volunteering activities, the amount of material support for social causes, and civic action (including a.o. signing petitions and participating in protest marches). A second measure, online civic engagement, is comprised of online communicative practices related to civil society causes (such as posting messages on social media with a societal or political topic). The final, and most abstract, dimension of civic engagement is civic identity, which relates to the connectedness one feels with the city and local government as an identity. As was hypothesized, civic engagement $(\mathrm{r}=0.17, \mathrm{p}<.005)$, online civic engagement $(\mathrm{r}=0.28, \mathrm{p}<.001)$ and civic identity $(\mathrm{r}=0.36$, $\mathrm{p}>.001$ ) correlate well with platform users' funding intentions. 


\section{Understanding Civic Crowdfunding as a Mechanism for Leveraging Civic Engagement and Urban Innovation Bastiaan Baccarne, Tom Evens, Lieven De Marez}

The rising correlation coefficients for higher levels of abstraction suggest that civic crowdfunding can be a mechanism to convert latent urban engagement into action. A multiple regression of these three constructs on crowdfunding intention $\left(\mathrm{R}^{2}=0.188, \mathrm{~F}=20.18, \mathrm{df}=3\right.$, $\mathrm{p}<.001)$ shows that civic identity $(\beta=0.35, \mathrm{t}=5.76 ; \mathrm{p}<.001)$ and online civic participation $(\beta=0.21, \mathrm{t}=3.91, \mathrm{p}<.001)$ are better predictors than traditional civic engagement $(\beta=0.06, t=0.77, p=.44)$. This supports the assumption that participation in urban crowdfunding is still considered as a relatively new mode of civic engagement, which appeals to new publics, thus allowing new modes of action.

In other words, civic crowdfunding serves a limited group, a 'participation elite', with new instruments to look for support and engage communities in the realization of their social enterprise ideas. However, this does not necessarily imply that the urban environment is tailored to the needs of only those 'happy few'. The deliberation process is not shaped by traditional participating publics, but rather through the activation of "new publics" that make more use of digital instruments in an online connected world.

\section{Institutionalized Civic Crowdfunding}

This brings us to the role of governments and the institutionalized aspects of civic crowdfunding. As discussed above, campaign instigators are often well connected with local governments. They consider the government reliable, goal-aligned, and transparent. Furthermore, they consider governments as necessary actors in molding public space. On the other hand, governments are also considered as slow and bureaucratic.

Although some interviewees mentioned their concerns about neo-liberal budget cut strategies and outsourcing public investments (subsidies) to society, most considered civic entrepreneurship, fueled by civic crowdfunding, as a bypass for such governmental inertia. As such, campaign instigators prefer their own entrepreneurial activities over urban innovation executed by local governments. However, governments are also considered as trust brokers between civic entrepreneurs and city inhabitants. Regarding the relationship with existing governmental support mechanisms for civic entrepreneurship, attitudes varied with some believing online crowdfunding offers a new mode of public financing, even for projects by the government itself. Others have explicitly taken a distance from these ideas, viewing civic crowdfunding as a strictly bottom-up mechanism. These two dimensions were also studied from a citizen-funders perspective to understand its relationship with funding intention.

More specifically, in addition to the concept of political efficacy, the in-depth interviews distinguished two additional constructs: (1) openness to governmental involvement ("The crowdfunding website can be a supplementary funding source for those projects the municipality lacks the resources to execute." Interviewee) and (2) government as a trust enhancer ( "The active role of the municipality increases my trust in the execution of the projects." - Interviewee). Both constructs show a good scale reliability (respectively $\alpha=0.72$ and $\alpha=0.73$; see addendum for scale items). The analysis shows a meaningful and significant correlation between civic crowdfunding intention and 'openness to governmental involvement' $(\mathrm{r}=0.21, \mathrm{p}<.001)$, as well as less significant correlations with 'government as a trust enhancer' $(\mathrm{r}=0.21, \mathrm{p}<.005)$ and 'political efficacy' $(\mathrm{r}=-$ $0.19, \mathrm{p}<.005$; negative formulation). However, in a multiple regression analysis on funding intention $\left(\mathrm{R}^{2}=.087, \mathrm{~F}=8.29, \mathrm{df}=3, \mathrm{p}<.001\right)$, none of these predictors show high levels of explanatory power.

\section{Quantitative summary table}

Table 2 provides an overview of the main quantitative research results. Overall, this research shows the limited importance of socio-demographic aspects when explaining differences in funding intentions, besides the (small, but significant) role of age $\left(\mathrm{R}^{2}=0.04\right)$. Although aspects of digital citizenship (and digital divides) correlate well with funding intentions, these aspects have equally limited predictive power regarding such intentions $\left(\mathrm{R}^{2}=0.06\right)$, similar to attitudes towards the government $\left(\mathrm{R}^{2}=0.08\right)$. An important aspect in explaining differences in funding intention, however, is the gratification sought, which reveals community altruism as the most important predictor of funding behavior $\left(\mathrm{R}^{2}=0.16\right)$. Finally, aspects related to civic engagement, especially civic identity, appear to be the most determining $\left(\mathrm{R}^{2}=0.19\right)$.

\section{Conclusion and Reflection}

This research investigated dynamics of governmentinitiated civic crowdfunding platforms to better understand these innovative ICT-enabled interaction interfaces for collective urban innovation with regards to participation inequalities and its defining dimensions. 


\section{Understanding Civic Crowdfunding as a Mechanism for Leveraging Civic Engagement and Urban Innovation Bastiaan Baccarne, Tom Evens, Lieven De Marez}

Table 2. Explaining differences in funding intentions (summary table)

\begin{tabular}{|c|c|c|c|c|c|}
\hline & \multicolumn{2}{|c|}{$\begin{array}{c}\text { bivariate } \\
\text { relationship } \\
\text { with funding } \\
\text { intention }\end{array}$} & \multicolumn{2}{|c|}{$\begin{array}{l}\text { multivariate } \\
\text { relationship } \\
\text { with funding } \\
\text { intention }{ }^{a}\end{array}$} & \multirow[t]{2}{*}{$\begin{array}{l}\text { hypothesis } \\
\text { supported? }\end{array}$} \\
\hline & $\mathrm{r}|\mathrm{t}| \mathrm{F}$ & $\mathrm{p}$ & $\beta$ & $\mathrm{p}$ & \\
\hline \multicolumn{6}{|l|}{ Socio-demographic } \\
\hline Level of education & 2.04 & 0.07 & & & not supported \\
\hline Occupation & 1.61 & 0.11 & & & not supported \\
\hline Income & -0.08 & 0.21 & & & not supported \\
\hline Residency & 0.85 & 0.34 & & & not supported \\
\hline Gender & -0.93 & 0.35 & & & not supported \\
\hline Age & $-0.21 * *$ & $<0.001$ & & & fully supported \\
\hline \multicolumn{6}{|l|}{ Funding motivations } \\
\hline Community altruïsm & $0.41^{* *}$ & $<0.001$ & & & fully supported \\
\hline Individual material reward & 0.10 & 0.10 & & & not supported \\
\hline $\begin{array}{l}\text { Individual non-material } \\
\text { reward }\end{array}$ & $0.18^{*}$ & 0.01 & & & $\begin{array}{l}\text { partially } \\
\text { supported }\end{array}$ \\
\hline Support strong ties & -0.08 & 0.19 & & & not supported \\
\hline \multicolumn{6}{|l|}{ Digital citizenship } \\
\hline Digital operational skills & $0.23 * *$ & $<0.001$ & 0.13 & 0.11 & $\begin{array}{l}\text { partially } \\
\text { supported }\end{array}$ \\
\hline Digital engagement & $0.25 * *$ & $<0.001$ & $0.21 *$ & 0.02 & $\begin{array}{l}\text { partially } \\
\text { supported }\end{array}$ \\
\hline \multicolumn{6}{|l|}{ Civic engagement } \\
\hline Civic engagement & $0.17 *$ & $<0.005$ & 0.06 & 0.44 & $\begin{array}{l}\text { partially } \\
\text { supported }\end{array}$ \\
\hline Online civic engagement & $0.28^{* *}$ & $<0.001$ & $0.21 * *$ & $<0.001$ & fully supported \\
\hline Civic identity & $0.36^{* *}$ & $<0.001$ & $0.35^{* *}$ & $<0.001$ & fully supported \\
\hline \multicolumn{6}{|l|}{$\begin{array}{l}\text { Attitude towards } \\
\text { government }\end{array}$} \\
\hline Political efficacy (neg.) & $-0.19^{*}$ & $<0.005$ & $-0.17 *$ & 0.01 & $\begin{array}{l}\text { partially } \\
\text { supported }\end{array}$ \\
\hline $\begin{array}{l}\text { Openness to governmental } \\
\text { involvement }\end{array}$ & $0.21 * *$ & $<0.001$ & $0.16^{*}$ & 0.04 & $\begin{array}{l}\text { partially } \\
\text { supported }\end{array}$ \\
\hline $\begin{array}{l}\text { Government as a trust } \\
\text { enhancer }\end{array}$ & $0.21 * *$ & $<0.005$ & 0.16 & 0.06 & $\begin{array}{l}\text { partially } \\
\text { supported }\end{array}$ \\
\hline
\end{tabular}

a No multiple regression is reported when only one predictor was significantly related at a $\mathrm{p}<0.005$ confidence level.

As a result, we began to provide guidance for the many associated institutional governance challenges. Our research revealed high levels of civic engagement for project instigators, which is related to a positive partnership attitude towards the local government, which they consider reliable, aligned with their needs, transparent, and necessary for innovation in the public space. This is also represented an institutionalized subset of what often comes across as antigovernmental tactical urbanism initiatives. Although 


\section{Understanding Civic Crowdfunding as a Mechanism for Leveraging Civic Engagement and Urban Innovation Bastiaan Baccarne, Tom Evens, Lieven De Marez}

project instigators perceive the local government as slow and bureaucratic, their governance role adds credibility and trust to the crowdfunding process.

However, to reach true success in crowdfunding, campaigns depend on different kinds of online and offline interactions. Through these interactions, existing social capital generates new ties with civic organizations and neighborhood residents (Stiver et al., 2015). Hence, online crowdfunding is perceived as a process to strengthen local ties and to improve neighborhood cohesion. Interestingly, however, online civic crowdfunding behavior of citizens was not seen as being related to broader practices of traditional civic engagement. This finding adds to the theoretical understanding of new participatory platforms. Although several authors claim that this innovative tool mainly empowers a traditional 'participation elite' that shapes the urban environment to their needs, this does not seem to be valid for civic crowdfunding, as the deliberation process involves new participatory publics and can be considered as a collaborative peer-to-peer funding instrument for co-produced urban innovation (Carè et al., 2018). There is, however, a very strong relationship between the intention to fund and a sense of civic identity, which relates to the neighborhood capacity building dynamics of civic crowdfunding.

Similarly, the research results show that community altruism is an important factor in predicting civic crowdfunding behavior. Rather than individual returns, participation is driven by societal goals such as helping others, tackling social challenges, and becoming part of a community (Carè et al., 2018). However, digital divides also formulate possible barriers for participation. This implies a potential divide between those who are highly engaged in digital media and those who are struggling with it or getting left behind.

The research shows that participation in civic crowdfunding is indeed partially embedded in broader practices of digital engagement. The success of crowdfunding campaigns, however, is more complex and dependent on both offline and online interactions, as a way of extending beyond the digital interface, which nuances traditional digital divide insights (Stiver et al., 2015). Furthermore, contrary to what was expected, neither income, nor education have a significant role in predicting participation behavior, although age does (younger citizens have a higher funding intention).
From a managerial perspective, considering the role of the government in leveraging social entrepreneurship though civic crowdfunding, the results show that government-ownership has a trust-enhancing role. This stimulates funding intention among citizens and social entrepreneurs, and also includes increased legitimacy of collaborative urban innovation processes in public environments. Such legitimacy is, of course, dependent on the inclusivity of civic crowdsourcing. In line with Hui et al. (2014), we conclude that the strong reliance on the involvement of a broad community is beneficial for civic entrepreneurship and urban innovation, since this implies that projects are constantly evaluated and collaboratively molded by funding communities throughout a campaign. However, the inclusivity of civic crowdfunding processes mainly depends on fostering a broader collective identity (rather than traditional digital divides), which is a topic beyond the scope of this paper.

Hence, when considering participation inequalities, it should be clear that these rely upon hyperlocal social dynamics, in which technology plays an intermediate role, one that both captures and catalyzes neighborhood capacities. This research shows that online civic crowdfunding itself can be considered as an innovative intervention that stimulates a new generation of network ties that extend individual civic crowdfunding campaigns. Hence, considering the importance of the crowd over the funding, both theoretical and managerial (strategic and practical) attention should be given to community dynamics, such as neighborhood cohesion and the construction and maintenance of a collective identity. 


\section{Understanding Civic Crowdfunding as a Mechanism for Leveraging Civic Engagement and Urban Innovation Bastiaan Baccarne, Tom Evens, Lieven De Marez}

\section{References}

Adler, R.P., \& Goggin, J. 2005. What Do We Mean By "Civic Engagement"? Journal of Transformative Education, 3(3): 236-253.

Albrecht, S. 2006. Whose voice is heard in online deliberation?: A study of participation and representation in political debates on the internet. Information, Communication \& Society, 9(1): 62-82.

Atkins, R., \& Hart, D. 2003. Neighborhoods, adults, and the development of civic identity in urban youth. Applied Developmental Science, 7(3): 156-164.

Bobek, D., Zaff, J., Li, Y., \& Lerner, R.M. 2009. Cognitive, emotional, and behavioral components of civic action: Towards an integrated measure of civic engagement. Journal of Applied Developmental Psychology, 30(5): 615-627.

Brabham, D.C. 2009. Crowdsourcing the public participation process for planning projects. Planning Theory, 8(3): 242-262.

Brenner, N., \& Theodore, N. 2002. Cities and the Geographies of "Actually Existing Neoliberalism." Antipode, 34(3): 349-379.

Byrne, D. N. 2007. Public discourse, community concerns, and civic engagement: Exploring black social networking traditions on BlackPlanet. com. Journal of Computer-Mediated Communication, 13(1): 319-340.

Carè, S., Trotta, A., Carè, R., \& Rizzello, A. 2018. Crowdfunding for the development of smart cities. Business Horizons, 61(4): 501-509.

Castells, M. 2007. Communication, power and counterpower in the network society. International Journal of Communication, 1(2007): 238-266.

Charbit, C., \& Desmoulins, G. 2017. Civic crowdfunding: A collective option for local public goods? Paris: OECD Regional Development.

Craig, S.C., Niemi, R.G., Silver, G.E., Craig, S.C., Niemi, R.G., et al. 2017. Political Efficacy and Trust: A Report on the NES Pilot Study Items. Political Behavior, 12(3): 289-314.

Davies, R. 2015. Three Provocations for Civic Crowdfunding. Information, Communication and Society, 18(3): 1-18.

Davis, F. 1989. Perceived usefulness, perceived ease of use and user acceptance of information technology. MIS Quarterly, 13(3): 319-340.

de Lange, M., \& de Waal, M. 2013. Owning the city: New media and citizen engagement in urban design. First Monday, 18(11).

Dimaggio, P., Hargittai, E., Celeste, C., \& Shafer, S. 2004. Digital inequality: From unequal access to differentiated use. In K. Neckerman (Ed.), Social Inequality: 355-400. New York: Russell Sage Foundation.
Ehrlich, T. 2000. Civic responsibility and higher education. Cambridge, MA: Oryx Press.

Ekman, J., \& Amnå, E. 2012. Political participation and civic engagement: Towards a new typology. Human Affairs, 22(3): 283-300.

Fishbein, M., \& Ajzen, I. 1975. Belief, Attitude, Intention, and Behavior: An Introduction to Theory and Research. Reading, MA: Addison-Wesley.

Forlano, L. 2013. Making waves: Urban technology and the co-production of place. First Monday, 18(11).

Fredericks, J., \& Foth, M. 2013. Augmenting public participation: Enhancing planning outcomes through the use of social media and web 2.0. Australian Planner, 50(3): 244-256.

Hargittai, E., \& Hinnant, A. 2008. Digital Inequality: Differences in Young Adults' Use of the Internet. Communication Research, 35(5): 602-621.

Helsper, E.J., \& Eynon, R. 2013. Distinct skill pathways to digital engagement. European Journal of Communication, 28(6): 696-713.

Holverson, C. 2017. Overcoming Barriers to Adoption for Innovations in Policy. Innovations: Technology, Governance, Globalization, 11(3-4): 64-79.

Hui, J., Greenberg, M., \& Gerber, E. 2014. Understanding the role of Community in Crowdfunding Work. Proceedings of the 17th ACM conference on Computer supported cooperative work \& social computing: 62-74.

Janssen, M., \& Estevez, E. 2013. Lean government and platform-based governance-Doing more with less. Government Information Quarterly, 30(S1): S1-S8.

Jenkins, H., Clinton, K., Purushotma, R., Robison, A.J., \& Weigel, M. 2006. Confronting the Challenges of Participatory Culture: Media Education for the 21 Century. White Paper for MacArthur Foundation.

Jugert, P., Eckstein, K., Noack, P., Kuhn, A., \& Benbow, A. 2013. Offline and Online Civic Engagement Among Adolescents and Young Adults from Three Ethnic Groups. Journal of Youth and Adolescence, 42(1): 123135.

Kligler-vilenchik, N. 2017. Alternative citizenship models: Contextualizing new media and the new " good citizen." New Media \& Society, 19(11): 1887-1903.

Koopman, C., Mitchell, M.D., \& Thierer, A.D. 2015. The Sharing Economy and Consumer Protection Regulation: The Case for Policy Change. The Journal of Business, Entrepreneurship \& the Law, 8(2): 529-546.

Lee, C.H., Zhao, J.L., \& Hassna, G. 2016. Governmentincentivized crowdfunding for one-belt, one-road enterprises: design and research issues. Financial Innovation, 2(2): 1-14.

Logue, D., \& Grimes, M. 2019. Platforms for the people: Enabling civic crowdfunding through the cultivation of institutional infrastructure. Strategic Management Journal, November (online first): 1-31. 


\section{Understanding Civic Crowdfunding as a Mechanism for Leveraging Civic Engagement and Urban Innovation Bastiaan Baccarne, Tom Evens, Lieven De Marez}

Mayer, M. 2018. Examining Community Dynamics of Civic Crowdfunding Participation. Computer Supported Cooperative Work: CSCW: An International Journal, 27(3-6): 1137-1151.

Mollick, E. 2014. The dynamics of crowdfunding: An exploratory study. Journal of Business Venturing, 29(1): 1-16.

Mossberger, K., Tolbert, C.J., \& Mcneal, R.S. 2008. Digital Citizenship: The internet, society and participation. Cambridge, MA: MIT Press.

Norris, P. 2001. Digital divide: Civic engagement, information poverty, and the Internet worldwide. Cambridge, MA: Cambridge University Press.

Ostertag, S.F., \& Ortiz, D.G. 2015. "Katrina bloggers activate!": The long-term effects of digital media on civic participation. Sociological Inquiry, 85(1): 28-54.

Preece, J., \& Shneiderman, B. 2009. The Reader-toLeader Framework: Motivating Technology-Mediated Social Participation. AIS Transactions on HumanComputer Interaction, 1(1): 13-32.

Stern, M., \& Dillman, D. 2006. Community participation, social ties, and use of the internet. City \& Community, 5(4): 409-424.

Stiver, A., Barroca, L., Minocha, S., Richards, M., \& Roberts, D. 2015. Civic crowdfunding research: Challenges, opportunities, and future agenda. New Media and Society, 17(2): 249-271.

Talò, C., \& Mannarini, T. 2015. Measuring Participation: Development and Validation the Participatory Behaviors Scale. Social Indicators Research, 123(3): 799-816.

Tonkens, E., Trappenburg, M., Hurenkamp, M., \& Schmidt, J. 2015. Montessori-democratie. Spanningen tussen burgerparticipatie en de lokale politiek. Amsterdam: Amsterdam University Press.

van Deursen, A., Helsper, E., \& Eynon, R. 2014. Measuring Digital skills. From Digital Skills to Tangible Outcomes project report. Retreived from Www.Oii.Ox.Ac.Uk/Research/Projects/?Id=112.

Van Dijk, J., \& Hacker, K. 2003. The digital divide as a complex and dynamic phenomenon. The Information Society, 19: 315-326.

Warren, A.M., Sulaiman, A., \& Jaafar, N.I. 2014. Social media effects on fostering online civic engagement and building citizen trust and trust in institutions. Government Information Quarterly, 31(2): 291-301.

Yin, R. 1984. Case study research. Beverly Hills, CA: Sage Publications.

\section{About the Authors}

Dr. Bastiaan Baccarne is a senior researcher at imecmict-Ghent University, Belgium. His academic interests converge on the crossroads between urban challenges, (urban) living labs, civic technology and smart cities. His work focusses on the potential and development of new interfaces in the urban environment to solve wicked urban issues. In September 2019, Bastiaan finished his $\mathrm{PhD}$ on innovative ICT-enabled interaction interfaces in the urban environment, titled: "collaborative and participatory challenges in urban innovation". This includes research on online civic engagement, digital citizenship, urban commons, innovation ecosystems and urban social informatics.

Professor Tom Evens is Assistant Professor at the Department of Communication Sciences at Ghent University, Belgium. He holds Masters Degrees in Communication Sciences (2005) and Business Administration (2006) from Ghent University. Tom teaches in Media Economics (Ba1), Innovation and Tech Policy (Ma) and Business Models in Media and Technology (Ma). He is fellow holder of the chair 'Media in a Society in Transition'.

Professor Lieven De Marez holds degrees in in communication sciences (1999) and marketing (2000), and a PhD on the 'Diffusion of ICTinnovations: more accurate user insight for better introduction strategies'. He heads the interdisciplinary research group imec-mict-Ghent University, Belgium, a group of approx. 50 researchers teaming up around a mission to empower users in a digitizing society. His personal research focus is on methodological innovation to feel the digital pulse of users in a digitizing society.

Citation: Baccarne, B., Evens, T., De Marez, L. 2020. Understanding Civic Crowdfunding as a Mechanism for Leveraging Civic Engagement and Urban Innovation. Technology Innovation Management Review, 10(5): 51-66. http://doi.org/10.22215/timreview/1356

\section{(cc) BY}

Keywords: Civic crowdfunding, Urban innovation, Civic entrepreneurship, Participation inequalities, Civic engagement, Digital citizenship, Peer-to-peer economy, Social cohesion, Civic identity. 


\section{Understanding Civic Crowdfunding as a Mechanism for Leveraging Civic Engagement and Urban Innovation Bastiaan Baccarne, Tom Evens, Lieven De Marez}

\section{Addendum}

Table 3. Survey sample description $(\mathrm{N}=265)$

\begin{tabular}{lcccc}
\hline & N & $\%$ & Mean & S.D. \\
\hline Age & 265 & & 34.73 & 18.20 \\
\hline Gender & & & & \\
\hline Male & 113 & 42.6 & & \\
Female & 152 & 57.4 & & \\
\hline Education & \multicolumn{4}{l}{} \\
None & 1 & 0.4 & & \\
high school or less & 10 & 3.8 & & \\
bachelor's degree short-type & 100 & 37.7 & & \\
bachelor's degree long-type & 81 & 30.6 & & \\
master's degree & 66 & 24.9 & & \\
doctoral degree & 7 & 2.6 & & \\
\hline
\end{tabular}

Table 4. Campaign instigator sample description (interviews, $\mathrm{N}=28$ )

\begin{tabular}{|c|c|c|}
\hline & $\mathbf{N}$ & $\%$ \\
\hline \multicolumn{3}{|l|}{ Gender } \\
\hline Male & 16 & $57 \%$ \\
\hline Female & 12 & $43 \%$ \\
\hline \multicolumn{3}{|l|}{ Education } \\
\hline high school or less & 5 & $18 \%$ \\
\hline bachelor's degree short-type & 9 & $32 \%$ \\
\hline bachelor's degree long-type & 0 & $0 \%$ \\
\hline master's degree & 14 & $50 \%$ \\
\hline \multicolumn{3}{|l|}{ Age } \\
\hline $20-30$ & 8 & $29 \%$ \\
\hline $30-40$ & 8 & $29 \%$ \\
\hline $40-50$ & 9 & $32 \%$ \\
\hline $50-70$ & 3 & $11 \%$ \\
\hline \multicolumn{3}{|l|}{ Campaign status } \\
\hline Success & 15 & $54 \%$ \\
\hline Failed & 5 & $18 \%$ \\
\hline Active & 8 & $29 \%$ \\
\hline \multicolumn{3}{|l|}{ Obtained funding } \\
\hline$<€ 1,000$ & 2 & $7 \%$ \\
\hline$€ 1,000-€ 5000$ & 8 & $29 \%$ \\
\hline$€ 5000-€ 15,000$ & 7 & $25 \%$ \\
\hline$>€ 15,000$ & 11 & $39 \%$ \\
\hline
\end{tabular}




\section{Understanding Civic Crowdfunding as a Mechanism for Leveraging Civic Engagement and Urban Innovation Bastiaan Baccarne, Tom Evens, Lieven De Marez}

Table 5. Constructs and correlations with funding intention (1/3)

\begin{tabular}{|c|c|c|c|c|c|c|}
\hline Construct & $\begin{array}{l}\text { Factor } \\
\text { loading }\end{array}$ & $\begin{array}{c}\text { Cronbach's } \\
\alpha\end{array}$ & Mean & S.D. & $\mathbf{r}$ & $\mathbf{p}$ \\
\hline Behavioral intention & & 0.87 & 4.13 & 1.42 & - & - \\
\hline $\begin{array}{l}\text { Funding such civic } \\
\text { crowdfunding projects is a good } \\
\text { idea }\end{array}$ & 0.82 & & & & & \\
\hline $\begin{array}{l}\text { I expect to fund such civic } \\
\text { crowdfunding project in the } \\
\text { future }\end{array}$ & 0.92 & & & & & \\
\hline $\begin{array}{l}\text { I am planning to fund such civic } \\
\text { crowdfunding projects. }\end{array}$ & 0.93 & & & & & \\
\hline $\begin{array}{l}\text { Community altruïsm } \\
\text { If I would fund such a project, it } \\
\text { would be to ... }\end{array}$ & & 0.68 & 5.23 & 0.96 & 0.41 & $\begin{array}{c}< \\
0.001\end{array}$ \\
\hline ... help people with a good idea & 0.75 & & & & & \\
\hline $\begin{array}{l}\text {... contribute to a societal } \\
\text { challenge }\end{array}$ & 0.72 & & & & & \\
\hline ... improve my neighborhood & 0.69 & & & & & \\
\hline ... be part of a community & 0.56 & & & & & \\
\hline $\begin{array}{l}\text { Individual rewards } \\
\text { If I would fund such a project, it } \\
\text { would be to ... }\end{array}$ & & 0.45 & - & - & - & - \\
\hline ... receive a material reward & 0.82 & & 3.40 & 1.80 & 0.10 & 0.10 \\
\hline $\begin{array}{l}\text {... receive a non-material } \\
\text { reward }\end{array}$ & 0.77 & & 4.42 & 1.80 & 0.18 & 0.01 \\
\hline $\begin{array}{l}\text { Strong ties } \\
\text { If I would fund such a project, it } \\
\text { would be to ... }\end{array}$ & & & & & & \\
\hline ... support people I know well & 0.88 & & 4.43 & 1.76 & -0.08 & 0.19 \\
\hline
\end{tabular}




\section{Understanding Civic Crowdfunding as a Mechanism for Leveraging Civic Engagement and Urban Innovation Bastiaan Baccarne, Tom Evens, Lieven De Marez}

Table 5. Constructs and correlations with funding intention, cont'd (2/3)

\begin{tabular}{|c|c|c|c|c|c|c|}
\hline Digital operational skills & & 0.80 & 5.27 & 1.31 & 0.23 & $\begin{array}{c}< \\
0.001\end{array}$ \\
\hline $\begin{array}{l}\text { I'm skilled in installing new } \\
\text { programs on a computer }\end{array}$ & 0.78 & & & & & \\
\hline $\begin{array}{l}\text { I'm skilled in installing new } \\
\text { devices on a computer }\end{array}$ & 0.70 & & & & & \\
\hline $\begin{array}{l}\text { Finding the right information } \\
\text { on the internet is hard for me } \\
\text { (recoded) }\end{array}$ & 0.72 & & & & & \\
\hline $\begin{array}{l}\text { I'm very interested in } \\
\text { computers }\end{array}$ & 0.68 & & & & & \\
\hline Digital engagement & & 0.89 & 5.92 & 1.19 & 0.25 & $\begin{array}{c}< \\
0.001\end{array}$ \\
\hline I often use search engines & 0.76 & & & & & \\
\hline I often read and send e-mails & 0.78 & & & & & \\
\hline I often use social media & 0.77 & & & & & \\
\hline I often visit news websites & 0.84 & & & & & \\
\hline $\begin{array}{l}\text { I use the internet for a lot of } \\
\text { different things }\end{array}$ & 0.77 & & & & & \\
\hline $\begin{array}{l}\text { The internet is very important } \\
\text { in my life }\end{array}$ & 0.74 & & & & & \\
\hline Civic Engagement & & 0.68 & 2.08 & 1.03 & 0.17 & $\begin{array}{c}< \\
0.005\end{array}$ \\
\hline Volunteer engagement & 0.74 & & & & & \\
\hline Material support & 0.81 & & & & & \\
\hline Civic action & 0.63 & & & & & \\
\hline Online Civic Engagement & & 0.91 & 2.36 & 1.54 & 0.28 & $\begin{array}{c}< \\
0.001\end{array}$ \\
\hline $\begin{array}{l}\text { I often like statuses, posts or } \\
\text { tweets with a societal or } \\
\text { political message. }\end{array}$ & 0.86 & & & & & \\
\hline $\begin{array}{l}\text { I often share statuses, posts or } \\
\text { tweets with a societal or } \\
\text { political message }\end{array}$ & 0.92 & & & & & \\
\hline $\begin{array}{l}\text { I often post messages on social } \\
\text { media with a societal or } \\
\text { political topic. }\end{array}$ & 0.90 & & & & & \\
\hline $\begin{array}{l}\text { I often encourage others online } \\
\text { to take action regarding societal } \\
\text { or political issues. }\end{array}$ & 0.84 & & & & & \\
\hline Civic Identity & & 0.81 & 5.08 & 1.33 & 0.36 & $\begin{array}{c}< \\
0.001\end{array}$ \\
\hline
\end{tabular}




\section{Understanding Civic Crowdfunding as a Mechanism for Leveraging Civic Engagement and Urban Innovation Bastiaan Baccarne, Tom Evens, Lieven De Marez}

Table 5. Constructs and correlations with funding intention, cont'd (3/3)

\begin{tabular}{|c|c|c|c|c|c|c|}
\hline $\begin{array}{l}\text { I am proud on my city } \\
\text { I feel connected with the } \\
\text { decisions in this city }\end{array}$ & $\begin{array}{l}0.86 \\
0.84\end{array}$ & & & & & \\
\hline Political efficacy & & 0.72 & 3.75 & 1.31 & -0.19 & $\begin{array}{c}< \\
0.005\end{array}$ \\
\hline $\begin{array}{l}\text { People like me don't influence } \\
\text { local policy }\end{array}$ & 0.84 & & & & & \\
\hline Voting is the only thing people & & & & & & \\
\hline like me can do to influence local & 0.78 & & & & & \\
\hline $\begin{array}{l}\text { care about what people like me } \\
\text { think }\end{array}$ & $0, .70$ & & & & & \\
\hline $\begin{array}{l}\text { Local politics is often so } \\
\text { complex that people like me } \\
\text { can't understand it. }\end{array}$ & 0.62 & & & & & \\
\hline $\begin{array}{l}\text { Openness to governmental } \\
\text { involvement }\end{array}$ & & 0.72 & 4.62 & 1.22 & 0.21 & $\begin{array}{c}< \\
0.001\end{array}$ \\
\hline $\begin{array}{l}\text { The municipality can also } \\
\text { publish crowdfunding projects } \\
\text { to finance them through the } \\
\text { website. }\end{array}$ & 0.86 & & & & & \\
\hline $\begin{array}{l}\text { The crowdfunding website can } \\
\text { be a supplementary funding }\end{array}$ & & & & & & \\
\hline $\begin{array}{l}\text { source for those projects the } \\
\text { municipality lacks the resources } \\
\text { to execute. }\end{array}$ & 0.79 & & & & & \\
\hline $\begin{array}{l}\text { The municipality can be } \\
\text { involved in the projects and the } \\
\text { way they are financed. }\end{array}$ & 0.65 & & & & & \\
\hline $\begin{array}{l}\text { Government as a trust } \\
\text { enhancer }\end{array}$ & & 0.73 & 4.72 & 1.16 & 0.21 & 0.001 \\
\hline The active role of the & & & & & & \\
\hline $\begin{array}{l}\text { municipality increases my trust } \\
\text { in the execution of the projects. } \\
\text { I don't think the municipality }\end{array}$ & 0.74 & & & & & \\
\hline $\begin{array}{l}\text { should be involved in such } \\
\text { projects. (rescaled) }\end{array}$ & 0.71 & & & & & \\
\hline $\begin{array}{l}\text { The active involvement of the } \\
\text { municipality increases my trust } \\
\text { in the financial transaction. }\end{array}$ & 0.68 & & & & & \\
\hline $\begin{array}{l}\text { I trust websites like these more } \\
\text { when a government is not } \\
\text { involved. (rescaled) }\end{array}$ & 0.67 & & & & & \\
\hline
\end{tabular}

